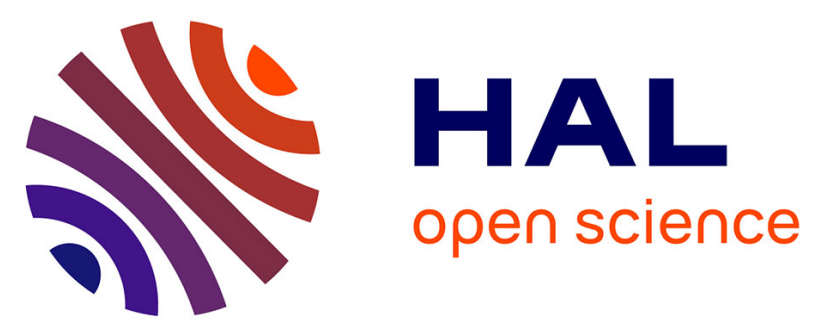

\title{
Bacterial adhesion and inactivation on Ag decorated TiO-nanotubes under visible light Effect of the nanotubes geometry on the photocatalytic activity
}

Ahmed El Hajjaji, M Elabidi, K Trabelsi, a A Assadi, B Bessais, S Rtimi

\section{- To cite this version:}

Ahmed El Hajjaji, M Elabidi, K Trabelsi, a A Assadi, B Bessais, et al.. Bacterial adhesion and inactivation on $\mathrm{Ag}$ decorated $\mathrm{TiO}-$ nanotubes under visible light Effect of the nanotubes geometry on the photocatalytic activity. Colloids and Surfaces B: Biointerfaces, 2018, 170, pp.92-98. 10.1016/j.colsurfb.2018.06.005 . hal-01834011

HAL Id: hal-01834011

https://hal-univ-rennes1.archives-ouvertes.fr/hal-01834011

Submitted on 13 Jul 2018

HAL is a multi-disciplinary open access archive for the deposit and dissemination of scientific research documents, whether they are published or not. The documents may come from teaching and research institutions in France or abroad, or from public or private research centers.
L'archive ouverte pluridisciplinaire HAL, est destinée au dépôt et à la diffusion de documents scientifiques de niveau recherche, publiés ou non, émanant des établissements d'enseignement et de recherche français ou étrangers, des laboratoires publics ou privés. 


\title{
Bacterial adhesion and inactivation on Ag decorated $\mathrm{TiO}_{2}$-nanotubes under visible light:
}

Effect of the nanotubes geometry on the photocatalytic activity.

\author{
A. Hajjaji ${ }^{1}$, M. Elabidi ${ }^{1}$, K. Trabelsi ${ }^{1}$, A.A. Assadi ${ }^{2}$, B. Bessais ${ }^{1 * *}$ and S. Rtimi ${ }^{3 *}$ \\ ${ }^{1}$ Laboratoire de Photovoltä̈que, Centre de Recherches et des Technologies de l'Energie, \\ Technopole de Borj-Cédria, BP 95, 2050 Hammam-Lif, Tunisia \\ ${ }^{2}$ Ecole Nationale Supérieure de Chimie de Rennes, CNRS, ISCR (Institut des Sciences Chimiques \\ de Rennes) - UMR 6226, F-35000 Rennes, France \\ ${ }^{3}$ Ecole Polytechnique Fédérale de Lausanne (EPFL), EPFL-STI-IMX-LTP, Station 12, CH-1015, \\ Lausanne, Switzerland \\ * Corresponding authors: S. Rtimi, sami.rtimi@epfl.ch, Tel: +41 216936803 \\ B. Bessais, brahim.bessais@ @rten.rnrt.tn, Tel: +216 79325215
}

\section{Statistical Summary:}

Abstract: 292 words

Main manuscript words: 5414 (not including figures captions)

Number of Figures: 7

Number of Tables: 1

\section{Graphical abstract:}

Bacterial inactivation is seen to be related to the nanotubes anodization potential and the silverions decoration. 


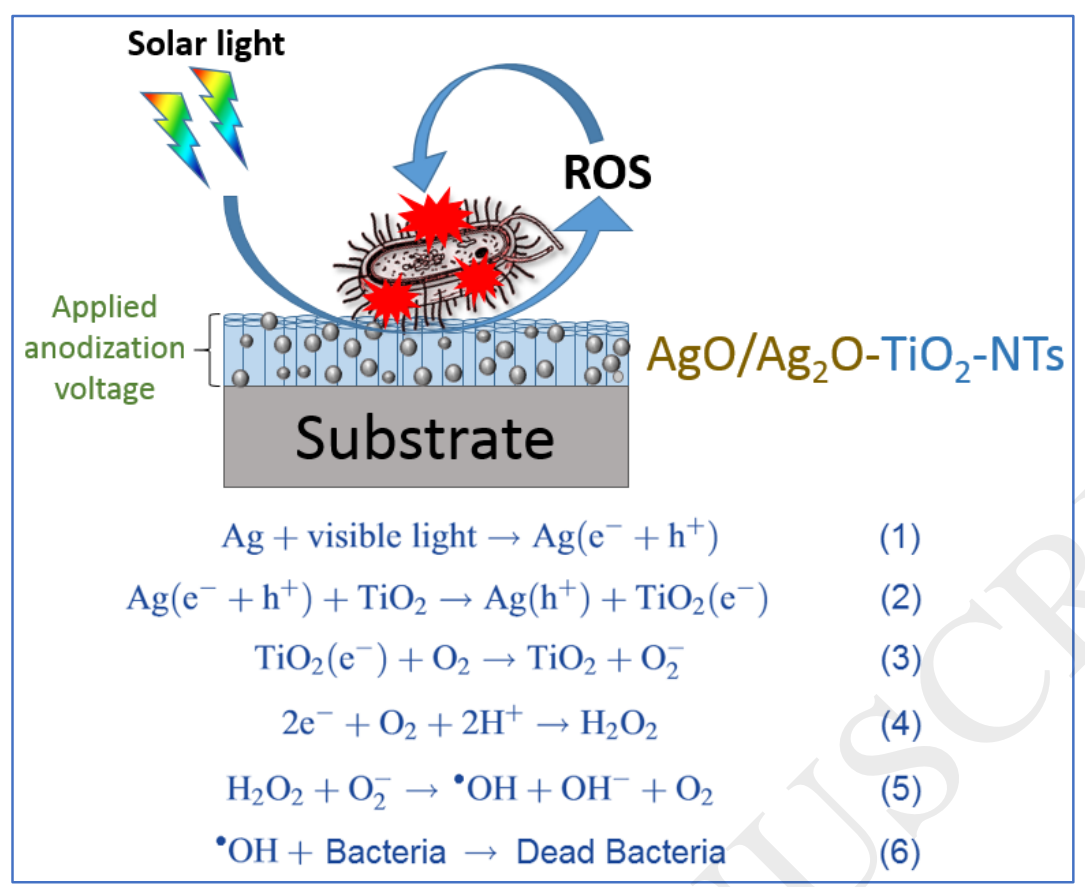

\title{
Highlights :
}

- $\mathrm{TiO}_{2}$ nanotubes decorated by silver nanoparticles were prepared

- Ag nanoparticles decoration was carried out using the photo-reduction process

- SEM and TEM imaging were used to see the microstructure of the nanotubes

- The effect of the NTs geometry on the bacterial inactivation was investigated

\begin{abstract}
:
This study investigates the effect of the diameter of $\mathrm{TiO}_{2}$ nanotubes and silver decorated nanotubes on optical properties and photocatalytic inactivation of Escherichia coli under visible light. The $\mathrm{TiO}_{2}$ nanotubes $\left(\mathrm{TiO}_{2}-\mathrm{NTs}\right)$ were prepared using the electrochemical method varying the anodization potential starting from $20 \mathrm{~V}$ until $70 \mathrm{~V}$. The Ag nanoparticles were carried out using the photoreduction process under the same experimental conditions. The diameter size was determined using the scanning electronic microscopy $(\mathrm{SEM})$. $\mathrm{TiO}_{2}-\mathrm{NTs}$ diameter reached $\sim 100 \mathrm{~nm}$ at $70 \mathrm{~V}$. Transmission electronic microscopy (TEM) imaging confirmed the $\mathrm{TiO}_{2}-\mathrm{NTs}_{\text {surface decoration }}$ by silver nanoparticles. The Ag-NPs average size was found to be equal to $8 \mathrm{~nm}$. The X-Ray
\end{abstract}


diffraction (XRD) analysis confirm that all $\mathrm{TiO}_{2}-\mathrm{NT}$ s crystallize in the anatase phases regardless the used anodization potential. The decrease of the photoluminescence (PL) intensity of Ag NPs decorated $\mathrm{TiO}_{2}$-NTs indicates the decrease of the specific area when the nanotubes diameter increases. The UV-Vis absorbance show that the absorption edges was bleu shifted with the increasing of nanotubes diameter, which can be explained by the increase of the crystallites average size. The bacterial adhesion and inactivation tests were carried in the dark and under light. Bacteria were seen to adhere on $\mathrm{TiO}_{2}$-NTs in the dark; however, under light the bacteria were killed before they establish a strong contact with the $\mathrm{TiO}_{2}-\mathrm{NTs}$ and $\mathrm{Ag} / \mathrm{TiO}_{2}-\mathrm{NTs}$ surfaces. Bacterial inactivation kinetics were faster when the anodizing potential of the NTs-preparation increases. A total bacterial inactivation was obtained on $\sim 100 \mathrm{~nm}$ nanotubes diameter within $90 \mathrm{~min}$. This result was attributed to the enhancement of the TNTs crystallinity leading to reduced surface defects. Redox catalysis was seen to occur under light on the $\mathrm{TiO}_{2}-\mathrm{NT}$ and $\mathrm{Ag} / \mathrm{TiO}_{2}-\mathrm{NT}$. the photo-induced antibacterial activity on the $\mathrm{AgO} / \mathrm{Ag}_{2} \mathrm{O}$ decorated $\mathrm{TiO}_{2}-\mathrm{NTs}$ was attributed to the interfacial charge transfer mechanism (IFCT).

Keywords: Ag decorated Titanium nanotubes, $\mathrm{AgO} / \mathrm{Ag}_{2} \mathrm{O}$, Nanotubes geometry, Crystallinity, Bacterial adhesion, Bacterial inactivation.

\section{INTRODUCTION}

Escherichia coli (E. coli) is hazardous bacteria that can cause distinct diarrhea syndrome. it was recognized as pathogen because it can cause urinary tract infection, hemolytic uremic syndrome and thrombotic thrombocytopenic purpura in human [1]. Thus, it is necessary to develop an effective material for the inactivation of $E$. coli.

Currently, the inactivation of bacteria is mainly through chemical products based on chloride as strong oxidant. Unfortunately, a big majority of these poducts produce carcinogenic disinfection by-products (DBPs) like trihalomethanes and haloacetic acids [2]. Oher products are based on bactericidal nanoparticles (mainly silver). These later products are showing limitations towards

some germs. In addition, some pathogens can develop resistance to silver nanoparticles as recently reported [3]. World Health Organization (WHO) launched an alert towards the excessive use of antibiotics and their derivatives [4]. Antibiotics are today showed to become ineffective against many pathogens that are able to develop resistance; hence, many germs became multidrug resistant. Thus, it is necessity today to develop alternative ways to disinfect surfaces in hospital facilities since healthcare acquired infections are increasingly threatening our lives [5-7]. 
Photocatalytic bacterial inactivation is found to be a promising alternative due to several advantages. The sustainable use of the photocatalytic material is one of the most unique properties of this method while conventional chemical root consumes disinfectants [8]. also this new method does not produce any toxic or carcinogenic product (DBPs). Additionally, Titanium dioxide $\left(\mathrm{TiO}_{2}\right)$ is attracting great attention during the last decades because of its chemical stability, non-toxicity, high oxidative power and low fabrication cost [5]. Titanium based photocatalysts have been used to inactivate bacteria (in the dark or under light irradiation) [9-10], virus [11] and even cancer cells/tumor [3-6]. However, the wide band gap energy (3.2 eV) and the high recombination rate of the photo-generated charges in $\mathrm{TiO}_{2}$ reduces its photocatalytic performance. To overcome this limitation, many strategies can be adopted like modifying $\mathrm{TiO}_{2}$ with anionic or cationic doping [12, 13], narrow-band semi-conductors coupling [14] or metallic nanoparticles decoration [15]. Although, it has been reported since years that anatase and rutile crystalline phases of $\mathrm{TiO}_{2}$ are more active than brookite form [16]. With respect to the photocatalytic activity of the polymorphs, although it is somewhat controversial, the anatase phase is generally regarded as being more active than rutile $[17,18]$. An emerging field of interest in photocatalysis is the development of $\mathrm{TiO}_{2}$ nanotubes $\left(\mathrm{TiO}_{2}-\mathrm{NTs}\right)$ and their coupling with cations, metal-oxides and additional composites leading to a higher nanocomposite sensitization in the visible range [19-21]. Titanium anodization is a simple preparation leading to controllable nanotubes formation, chemical resistivity, high surface area (2-3 orders of magnitude higher than a flat surface) and therefore high loading capability. The large surface to volume ration of $\mathrm{TiO}_{2}-\mathrm{NTs}$ is related to the large internal and external surfaces along with the surface in their vertex and the interstitial surface.

In this study, $\mathrm{TiO}_{2}-\mathrm{NT}$ s were prepared by anodic oxidation. After optimization of the $\mathrm{TiO}_{2}-\mathrm{NTs}$ antibacterial activity and geometry, the most active NTs were decorated with different amounts of silver nanoparticles (Ag NPs) using the photo-reduction method. We focus on the effect of NTs geometry before and after the Ag-decoration and its influence on the charge separation and transport. Furthermore, this decoration affected the optical properties and photocatalytic performance against $E$. coli under low intensity solar simulated light. We also show that varying the anodization potential during the nanotubes growth influences their geometry and reactivity under visible light.

\section{EXPERIMENTAL}




\subsection{Preparation of Ag-NPs/TiO 2 -NTs photo-electrodes}

The anodization was performed under continuous stirring during $2 \mathrm{~h}$ at room temperature and at different potential starting from $20 \mathrm{~V}$ to $70 \mathrm{~V}$. The electrolyte consisted of a mixture of 2 vol. $\%$ of water and ethylene glycol and $0.07 \mathrm{M}$ of $\mathrm{NH}_{4} \mathrm{~F}$. The as-prepared $\mathrm{TiO}_{2}-\mathrm{NTs}$ were rinsed with water, air dried, and then annealed for 3 hours at $400^{\circ} \mathrm{C}\left(5^{\circ} \mathrm{C} / \mathrm{min}\right)$. Subsequently, the prepared $\mathrm{TiO}_{2}-\mathrm{NTs}$ were decorated with Ag-NPs using the photo-reduction method. To this end, the $\mathrm{TiO}_{2}-\mathrm{NTs}$ were first immersed in a $0.1 \mathrm{M}$ solution of $\mathrm{AgNO}_{3}$ for 24 hours, then rinsed with water and immersed again in methanol under UV radiation $(254 \mathrm{~nm})$ for 10 minutes. Finally, the $\mathrm{Ag}-\mathrm{NPs} / \mathrm{TiO}_{2}-\mathrm{NTs}$ samples were rinsed with water and dried in a vacuum oven for $1 \mathrm{~h}$ at $80^{\circ} \mathrm{C}$.

\subsection{Evaluation of the adhesion and inactivation of $E$. coli on $\mathrm{Ag}-\mathrm{NPs} / \mathrm{TiO}_{2}-\mathrm{NTs}$ under light and dark conditions}

The antibacterial activity of the $\mathrm{Ag}-\mathrm{NPs} / \mathrm{TiO}_{2}-\mathrm{NTs}$ was performed taking Escherichia coli (E. coli K12 ATCC 23716; from the Deutsche Sammlung von Mikroorganismen und Zellkulturen GmbH (DSMZ), Braunschweig, Germany) as a probe. The samples were sterilized by autoclaving at $121^{\circ} \mathrm{C}$ for $2 \mathrm{~h}$. The $100 \mu \mathrm{L}$ culture aliquots with an initial concentration of $\sim 410^{6}$ Colony-forming unit per milliliter (CFU mL $\left.{ }^{-1}\right)$ in $\mathrm{NaCl} / \mathrm{KCl}(\mathrm{pH} 7)$ were placed on the samples. The $100 \mu \mathrm{L}$ of the E. coli inoculum was contacted with the Ag-NPs/TiO 2 -NTs uniform surface. The exposition was done at $23^{\circ} \mathrm{C}\left(+/-2^{\circ}\right)$. The samples were then placed on Petri dishes provided with a lid to prevent evaporation. After each determination, the surface was transferred into a sterile $2 \mathrm{~mL}$ Eppendorf tube containing $900 \mu \mathrm{L}$ autoclaved $\mathrm{NaCl} / \mathrm{KCl}$ saline solution. This solution was subsequently mixed thoroughly using a Vortex for $2 \mathrm{~min}$. Serial dilutions were made in $\mathrm{NaCl} / \mathrm{KCl}$ solution. A $100 \mu \mathrm{L}$ sample of each dilution was pipetted onto a nutrient agar plate and then spread over the surface of the plate using standard plating method. Agar plates were incubated lid down, at $37{ }^{\circ} \mathrm{C}$ for $24 \mathrm{~h}$ before colonies were counted. Three independent assays were done for each sample.

The statistical analysis of the results were performed for the CFU values calculating the standard deviation values. The average values were compared by one-way analysis of variance and with the value of statistical significance. The one-way analysis of variance (one-way ANOVA) was used to compare the mean of the samples using the Fisher distribution. The response variable was approximated for the sample data obtained from the photocatalytic inactivation of test samples presenting the same distribution within the same sample (prepared at fixed anodization voltage). 
To verify that no attached/adsorbed bacteria remained on the surface, samples were incubated for 24 hours at $37^{\circ} \mathrm{C}$ on agar. No bacterial re-growth was observed.

The samples were irradiated in the cavity of an Atlas solar simulator (Atlas, GmbH, Hanau, Germany) with an overall power of $50 \mathrm{~mW} / \mathrm{cm}^{2}$ with light distribution wavelength distribution resembling solar irradiation emitting at wavelengths between 310 and $800 \mathrm{~nm}$. The system contains an air-cooled Xenon lamp provided with filter to cut off wavelengths below $310 \mathrm{~nm}$ and above 800 nm. Samples were irradiated into covered glass petri dishes to avoid bacterial suspension evaporation due to the air-cooling. The material of the petri dishes does not cut the used light.

The adhesion of the E. coli on the $\mathrm{TiO}_{2}-\mathrm{NTs}$ and $\mathrm{Ag} / \mathrm{TiO}_{2}-\mathrm{NT}$ anodized surfaces was carried out by immersing the samples into $5 \mathrm{~mL}$ suspension of $E$. coli cell of a concentration of $410^{6}$ $\mathrm{CFU} / \mathrm{ml}$. The tube was then shacked gently at $37^{\circ} \mathrm{C}$ for $4 \mathrm{~h}$ in dark [22,23]. The non-adhered bacteria to the NTs were removed by washing the surface with phosphate buffer solution (pH 7.2). The number of viable cells was determined after detachment of the adhered E. coli cells by ultrasonication $(50 \mathrm{~W})$ for $15 \mathrm{~min}$. Non-adhered/weakly adhered bacteria on the surfaces were evaluated according to Hoffman [24]. Bacterial adhesion experiments were carried out in the dark to avoid the photocatalytic action of the $\mathrm{TiO}_{2}$ and $\mathrm{Ag} / \mathrm{TiO}_{2}$ surfaces.

\section{2-3. Characterizations}

The crystallinity and phase identification of the prepared samples were systematically investigated using X-ray diffraction (Philips X'PERT MPD, $\mathrm{Cu} \mathrm{K \alpha}$ irradiation, $\lambda=1.5406 \AA$ ). The diffraction data were collected over the diffraction angle range of $20^{\circ}-80^{\circ}$ with a scanning step of $0.016^{\circ}$. The morphology and nanostructure of the $\mathrm{Ag}-\mathrm{NPs} / \mathrm{TiO}_{2}-\mathrm{NTs}$ samples were examined by scanning electronic microscope (SEM, Jeol JSM-6300) and FEI Tecnai G2 transmission electron microscopy (TEM) operating at $200 \mathrm{kV}$ with a LaB6 filament. The local chemical analysis was performed using the energy dispersive X-ray spectroscopy (EDXS) system attached to the TEM.

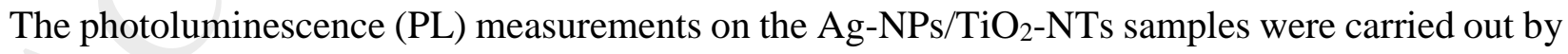
using a fluorescence spectrophotometer (Perkin Elmer LS55) equipped with a xenon lamp at an excitation wavelength of $\lambda=340 \mathrm{~nm}$. The XPS measurements were performed using an AXIS NOVA (Kratos Analytical, Manchester, UK) photoelectron spectrometer with an achromatic Al $\mathrm{K} \alpha \mathrm{X}$-ray source at $400 \mathrm{~W}$. The spectra were excited using Al $\mathrm{K} \alpha$ radiation (1486.6 eV). All XPS data were corrected from sample charging during XPS data acquisition, while using the C1s (284.6 $\mathrm{eV}$ ) peak as a reference. The base pressure below $510^{-9}$ mbar was maintained during the 
measurement. No argon sputtering was considered as to clean the coatings surface, neither ion or electron neutralizers were used during the measurement. The surface atomic concentration percentage for each element was determined from peak areas using the known sensitivity factors for each element $[25,26]$ on the surfaces. The spectrum background was subtracted according to Shirley [27] through the Shirley subtraction GL(30) program of the Kratos unit. The XPS spectra for the Ti and Ag-species were analyzed using CasaX-Vision 2 (Kratos Analytical, UK) and the peaks were assigned according to the NIST database. All measurements were done in the fixed analyzer transmission mode (FAT).

\section{RESULTS AND DISCUSSIONS}

X-ray diffraction (XRD) performed on the films showed Bragg reflections between 20 and $80^{\circ}$. Figure 1 shows the XRD spectra of the $\mathrm{Ag}-\mathrm{NPs} / \mathrm{TiO}_{2}-\mathrm{NTs}$, which confirm that all samples, are crystallized in the anatase phase. The extra peaks observed at $2 \theta=38.5^{\circ}, 40.4^{\circ}, 53.1^{\circ}, 63^{\circ}$, $70.8^{\circ}$ are due to the Ti metallic phase of the underlying substrate. The absence of silver related XRD peaks is mainly related to the very tiny amount of Ag NPs deposited on the $\mathrm{TiO}_{2}-\mathrm{NTs}$. $\mathrm{Ag} / \mathrm{TiO}_{2}$ material have been extensively studied. Table 1 shows the diameter of $\mathrm{TiO}_{2}-\mathrm{NTs}$ expressed as mean value ( \pm standard deviation) and the number of counted particles/NTs for the statistical analysis both for $\mathrm{Ag}-\mathrm{NPs}$ and for $\mathrm{TiO}_{2}-\mathrm{NT}$. Crystallite size of $\mathrm{TiO}_{2}-\mathrm{NT}$ s are also estimated by the mean of XRD Scherrer equation as previously reported in detail [21]. Page et al., reported on Silver-titania nanocomposite as potent antimicrobial material and reported XRD peaks assigned to $\mathrm{Ag}_{2} \mathrm{O}$ at $2 \theta=31.5^{\circ}$ [28]. For our composite, this peak was not observed. This can be attributed to the few amounts of Ag that are likely below the XRD sensitivity threshold. It is readily seen that even at low anodization potentials, Ti crystallizes in anatase phase. This is due to the annealing step for 3 hours at $400^{\circ} \mathrm{C}$ as described in the experimental section. Recently, Mateus et al., observed anatase phase in $\mathrm{TiO}_{2}$ nanotubes prepared by different chemical solutions/precursors such as water/fluorhydric acid/ammonium fluoride/ethylene glycol $\left(\mathrm{H}_{2} \mathrm{O} / \mathrm{HF} / \mathrm{NH}_{4} \mathrm{~F} / \mathrm{EG}\right)$ as well as the conditions of anodization. The same authors showed by the mean of UV-Vis measurements that the band-gap varied with to the anodizing time and solution [29].

Figure 2 Shows SEM top view images of Ag NPs decorated $\mathrm{TiO}_{2}-\mathrm{NT}$ s anodized respectively under potential $20 \mathrm{~V}$ (a) and $60 \mathrm{~V}$ (b). No tubular structures were seen when applying $20 \mathrm{~V}$. At lower potentials, the fields assisted dissolution was not strong enough to remove the first anodic 
layer formed at the beginning of the anodization and leading to the formation of NTs. Under $30 \mathrm{~V}$, the NTs were not clearly seen. However, under $60 \mathrm{~V}$ anodization, a highly ordered $\mathrm{TiO}_{2} \mathrm{NTs}$, vertically aligned onto the Ti-substrate were formed as seen in Figure $2 \mathrm{~b}$. Figure $2 \mathrm{c}$ shows the diameter size distribution of $\mathrm{TiO}_{2} \mathrm{NTs}$ anodized at $60 \mathrm{~V}$ with a mean diameter size of $97 \mathrm{~nm}$. Figure $3 \mathrm{~d}$ shows the evolution of mean diameter of $\mathrm{TiO}_{2}-\mathrm{NTs}$ as function of the applied anodization potentials. A maximum diameter size of $100 \mathrm{~nm}$ was reached for an anodization potential of $70 \mathrm{~V}$.

The size distribution of Ag NPs was carried out using TEM on the Ag NPs decorated $\mathrm{TiO}_{2}$ NTs sample anodized at $60 \mathrm{~V}$. Figure $3 \mathrm{a}$ (and the inset) shows a bare $\mathrm{TiO}_{2}-\mathrm{NT}$ s with typical outer diameter of $100 \mathrm{~nm}$ that confirm the SEM observation. The as-formed $\mathrm{TiO}_{2}-\mathrm{NTs}$ are seen in Figure $3 \mathrm{~b}$ to be highly ordered and vertically aligned onto the underlying Ti-substrate. The observed nanotubes is $100 \mathrm{~nm}$ present a length is of $\sim 15 \mu \mathrm{m}$ (see the SEM cross-section view in the inset of Figure 3b). Figure 3c shows the $\mathrm{TiO}_{2}-\mathrm{NT}$ s after their Ag NPs decoration, the Ag NPs are attached on the external wall of the tube. In order to find the average size of Ag-NPs. It is normally difficult to efficiently deposit $\mathrm{Ag}-\mathrm{NPs}$ in $\mathrm{TiO}_{2}$ nanotubes using the photo-reduction method. The TEM image were systematically analyzed as shown in Figure 3. The average size of Ag NPs decorating the $\mathrm{TiO}_{2}-\mathrm{NTs}$ is about $8+/-2 \mathrm{~nm}$.

Figure 4 shows the diffuse reflectance spectra of the anodized NTs. It is readily seen from Figure 4 that the spectral absorption of Ag-decorated samples are shifted to the visible region. The yellow zone of the figure shows the light emission of the used light source (solar simulated light, 310-800 nm). The UV-Vis absorbance spectra show that the absorption edges was bleu shifted with the increase of the NTs diameter, which can be explained by the increase of the crystallites average size. Although $\mathrm{TiO}_{2}$ is an indirect semiconductor and its energy gap is usually estimated by reflectance spectra, the difficulty to get accurate data (band-gaps) from DRS spectra in our case comes from the baseline/background correction before spectra acquisition. After anodization the substrate shows little colorization that is different from the raw material. This colorization limits to a large extend the possibility of using "non-anodized" material as baseline/background. Bandgaps (and intra-gap states) of the prepared NTs are described below by the mean of PL.

Figure 5 shows the typical PL spectra of $\mathrm{TiO}_{2}-\mathrm{NTs}$ and $\mathrm{Ag}$ decorated $\mathrm{TiO}_{2}-\mathrm{NT}$ s anodized at different potentials. When exited with UV light (see experimental) nano-crystalline $\mathrm{TiO}_{2}$ reveals a range of intra-bandgap defect states that emit at visible wavelengths as shown in the PL spectra. 
To probe the luminescent defect states of the anodized $\mathrm{TiO}_{2}-\mathrm{NTs}$ shown in this study, we used 340 $\mathrm{nm}$ excitation. The $\mathrm{TiO}_{2}$-NTs show a broad photo-luminescence in the visible (from 380 to 660 $\mathrm{nm}$ ) with a mono-modal peak at $390-450 \mathrm{~nm}$ or $2.7-3.1 \mathrm{eV}$. The PL spectra of $\mathrm{Ag} / \mathrm{TiO}_{2}-\mathrm{NTs}$ show bimodal peaks. The first peak $(390-450 \mathrm{~nm})$ corresponds to $\mathrm{TiO}_{2}-\mathrm{NTs}$; however, the second peak corresponds to the signal generated by Ag-NPs. This latter peak ranges from 460-650 nm corresponding to band energies 1.9-2.6 eV. The NTs defects were investigated through the shape and shifts in the intensity of the PL spectra correlated to electron/hole pairs and band-gap energies [30,31]. The increase of the photoluminescence (PL) intensity of $\mathrm{Ag} / \mathrm{TiO}_{2}-\mathrm{NTs}$ indicates the increase of the specific area when the nanotubes diameter increases. Figure $5 \mathrm{~b}$ shows the bacterial inactivation mechanism on $\mathrm{Ag}$-decorated $\mathrm{TiO}_{2}$-NTs. $\mathrm{Ag}$ NPs increase the separation of photogenerated charges and help in transferring the trapped electrons to the adsorbed $\mathrm{O}_{2}$. The Fermi level of Ag NPs is situated below the $\mathrm{TiO}_{2}$ conduction band. This promotes the interfacial charge transfer (IFCT) from $\mathrm{TiO}_{2}$-NTs to Ag-NPs [30] reducing consequently the charge recombination in $\mathrm{TiO}_{2}$.

XPS results showed the existence of $\mathrm{Ti}^{4+}$ and $\mathrm{Ti}^{3+}$ in the as-prepared samples. $\mathrm{TiO}_{2}-\mathrm{NTs}$ showed $89 \% \mathrm{Ti}^{4+}$ and $10 \% \mathrm{Ti}^{3+}$ as determined by XPS-peaks surface areas. $\mathrm{Ag} / \mathrm{TiO}_{2}-\mathrm{NTs}$ showed slightly different proportions of $81 \%$ and $19 \%$, respectively for $\mathrm{Ti}^{4+}$ and $\mathrm{Ti}^{3+}$. Before their use for the antibacterial activity tests, the samples undergo the autoclaving step. After autoclaving, the samples showed slightly different surface properties (oxidative states) as detected by XPS. After autoclaving, the $\mathrm{Ti}^{3+}$ content reached $22 \%$ for $\mathrm{TiO}_{2}-\mathrm{NTs}$ samples and up to $29 \%$ for $\mathrm{Ag} / \mathrm{TiO}_{2}-\mathrm{NTs}$ samples. These changes in the oxidative states can be attributed to the molecular disorders at the NTs interface after autoclaving $\left(\mathrm{H}_{2} \mathrm{O}_{\text {vapor }}\right.$ and pressure). After the bacterial inactivation time under light irradiation, the surface oxidative states were also followed. The $\mathrm{Ti}^{3+}$ was seen to increase in all samples to 33 to $41 \%$ respectively for $\mathrm{TiO}_{2}-\mathrm{NTs}$ and $\mathrm{Ag} / \mathrm{TiO}_{2}-\mathrm{NTs}$. Ti-oxidative states $\left(\mathrm{Ti}^{+3}\right.$ and $\left.\mathrm{Ti}^{+4}\right)$ have been reported to change between the as-prepared sample and the illuminated sample during the bacterial inactivation $[32,33]$. At these valences $(+3$ and +4$)$, the ionic radii are located between 0.65 and $0.88 \AA$. In addition, $\mathrm{Ag}$ species used to decorate the $\mathrm{TiO}_{2}-\mathrm{NTs}$ exhibit oxidative states of +1 and +2 . The ionic radii of these $\mathrm{Ag}$-species were calculated to be $0.67-1.28 \AA$ and 0.79 $0.94 \AA$ for $\mathrm{Ag}^{+}$and $\mathrm{Ag}^{2+}$, respectively [34]. Ahrens previously calculated these radii from bond length - bond strength equations [35]. The mechanism of bacterial inactivation on $\mathrm{Ag} / \mathrm{TiO}_{2}-\mathrm{NTs}$ was reported in many studies before and will not be discussed in deep details in the present work. 
Nonetheless, it is worth mentioning that this bacterial inactivation involves IFCT processes occurring between $\mathrm{AgO} / \mathrm{Ag}_{2} \mathrm{O}$ and $\mathrm{TiO}_{2}$ [36-38].

Figure 6 shows $E$. coli inactivation on $\mathrm{TiO}_{2}-\mathrm{NT}$ and $\mathrm{Ag}$ decorated $\mathrm{TiO}_{2}-\mathrm{NT}$ s under low intensity solar simulated light. The used light dose corresponds to the daylight dose during a cloudy day. It is readily seen in Figure 6 that $\mathrm{TiO}_{2}-\mathrm{NTs}$ by themselves reduced 1.6log E coli within 180 min. Ag decorated $\mathrm{TiO}_{2}-\mathrm{NTs}$ enhanced the bacterial inactivation. The fastest bacterial inactivation was seen to happen on $\mathrm{Ag} / \mathrm{TiO}_{2}-\mathrm{NTs}$ anodized at $60 \mathrm{~V}$ and $70 \mathrm{~V}$ inactivating $99.99 \%$ E. coli within $90 \mathrm{~min}$. It has been reported recently that bacteria can adhere to nanostructured $\mathrm{TiO}_{2}$ based surfaces due to Lifshitz-Van der Waals forces, hydrogen bonding, electrostatic interactions and Brownian motion interfacial forces $[39,40]$. This adhesion was also attributed to the cell wall proteins interaction with the surface [41] and the surface wettability at the solid-liquid interface [42]. E. coli adhesion on the $\mathrm{TiO}_{2}-\mathrm{NTs}$ and $\mathrm{Ag} / \mathrm{TiO}_{2}-\mathrm{NT}$ s in the dark showed that increasing the incubation time of bacteria with the surface increases the bacterial adhesion until a certain limit of $\sim 10^{3}$ $\mathrm{CFU} / \mathrm{ml} / \mathrm{cm}^{2}$. This load is weak compared to other surfaces able to harbor higher bacterial concentrations. This is due to: i) bacterial cell wall interaction with the polar groups on the NTssurface, ii) the wetting property of the NTs-surface (decorated with Ag or not), and iii) the surface potential "Eigenvalues" as recently reported [7]. It has been recently reported that the cell wall complexity controls the adhesion and invasion of biotic and abiotic surfaces [43]. Figure 6 shows that $E$. coli can adhere to $\mathrm{TiO}_{2}-\mathrm{NTs}$ in the dark. Under light, this bacterial adhesion facilitates the charge transfer between the photocatalyst and the bacterial cell wall leading to cell wall damage [44]. The $\mathrm{TiO}_{2}$ photo-switchable surface wettability was extensively reported in the literature $[45,46]$ and is beyond the scope of the present study focusing more on the effect of the NTs geometry on the bacterial inactivation. Figure 6 shows also a slight bacterial inactivation in the dark on $\mathrm{Ag} / \mathrm{TiO}_{2}-\mathrm{NTs}$. This can be due to the diffusion of $\mathrm{Ag}$-ions to the bacterial cytoplasm through the cell wall porins.

In addition, Figure 3d showed that the size distribution of Ag-NPs ranges from 1 to $12 \mathrm{~nm}$. Nowack et al., [47] reviewed the use of nano-silver and the associated antibacterial effect during the last decades. Rtimi et al., reported that the dissolution of Ag-NPs releasing Ag-ions and attributed the antibacterial activity to an oligodynamic effect $[48,14]$. These ions are able to penetrate the bacterial cell envelop, reaching the cytoplasm and inactivating the cell machinery and 
thus leading to cell death. Recent reports used porinless bacteria to not allow the penetration of Agions through the bacterial cell wall porins $[49,50]$. The same study showed that porinless E. coli inactivation was six times longer than normal/wild E. coli (with porins). This study gave the evidence that Ag-ions are not the only agent leading to the bacterial inactivation but that surfacecontact effects play also an important role through ROS and/or charge transfer [49-51]. E. coli has

a thinner peptidoglycan cell wall compared to the $S$. aureus and containing additional layers with a high structural complexity. The significant difference in the cell wall thickness/microstructure between these strains may lead to different interactions with $\mathrm{TiO}_{2}-\mathrm{NTs}$ and $\mathrm{Ag} / \mathrm{TiO}_{2}-\mathrm{NTs}$ surfaces. $\mathrm{TiO}_{2}$ was reported to damage the cell wall membrane through lipid-peroxidation [51] increasing the cell wall fluidity [32]. Nesic et al., reported recently on bacterial inactivation on $\mathrm{TiO}_{2}$ impregnated textiles in the dark $[9,33]$.

\section{CONCLUSION}

$\mathrm{TiO}_{2}$-NTs have been successfully prepared from the anodization of metallic Ti foils, and decorated them with Ag-NPs using the photochemical reduction method. By varying the anodization potential, we were able to increase the nanotubes diameter until reaching $100 \mathrm{~nm}$ for $70 \mathrm{~V}$. The increase of the anodization potential led to an increase in the crystallites sizes. It was also seen that PL spectra revealed band-gaps in the range of 2.7-3.1 eV for $\mathrm{TiO}_{2}$ and of 1.9-2.5 for $\mathrm{Ag}_{\mathrm{x}} \mathrm{O}$. The reduced surface defects of $\mathrm{TiO}_{2}$ where seen to enhance the photocatalytic bacterial inactivation kinetics. The maximum photocatalytic performance of $\mathrm{TiO}_{2}-\mathrm{NTs}$ is obtained for NTs anodized at 60 and $70 \mathrm{~V}$. Bacterial adhesion was seen to be favorable in the dark. Under light irradiation, the bacterial inactivation was seen to be faster on larger NTs prepared at 60-70 V. The Ag/TiO $2-\mathrm{NTs}$ reported in this study have the potential to open new industrial segments in the rapidly developing health sector. Further research is required to translate the present findings into performing industrial products e.g. medical devices and implants.

Acknowledgment: We thank the financial support from the Ministry of Higher Education, Scientific Research and Technology of Tunisia. We also thank the Swiss Federal Institute of Technology in Lausanne (EPFL). This article is dedicated to the retirement of Prof. H. Hofmann a key figure in the Nano-Bio-interactions at EPFL.

\section{REFERENCES}


[1] E. A. Zottola and L. B. Smith, The microbiology of foodborne disease outbreaks: an update, J. Food Safe 11 (1990) 13-29.

[2] K. Gopal, S. S. Tripathy, J. L. Bersillon, S. P. Dubey, Chlorination byproducts, their toxicodynamics and removal from drinking water, J. Hazard. Mater. 140 (2007) 1-6.

[3] J. L.Graves Jr, M. Tajkarimi, Q. Cunningham, A. Campbell, H. Nonga, S. H. Harrison, J.E. Barrick, Rapid evolution of silver nanoparticle resistance in Escherichia coli, Frontier in Genetics 6 (2015) Article 42.

[4] V. Tangcharoensathien, S. Chanvatik, A. Sommanustweechai, Complex determinants of inappropriate use of antibiotics, Bull World Health Organ 96 (2018) 141-144.

[5] S. Rtimi, Indoor Light Enhanced Photocatalytic Ultra-Thin Films on Flexible Non-Heat Resistant Substrates Reducing Bacterial Infection Risks, Catalysts 7 (2017) 57.

[6] M.K.S. Ballo, S. Rtimi, J. Kiwi, C. Pulgarin, J.M. Entenza, A. Bizzini, Fungicidal activity of copper-sputtered flexible surfaces under dark and actinic light against azole-resistant Candida albicans and Candida glabrata, Journal of Photochemistry \& Photobiology, B: Biology 174 (2017) 229-234.

[7] A. Camarasa Mena, S. Rtimi, C. Pulgarin, J-C Lavanchy, J. Kiwi, Grafted semiconductors on PE-films leading to bacterial inactivation: synthesis, characterization and mechanism, Colloids and Surfaces A: Physicochemical and Engineering Aspects 519 (2017) 231-237.

[8] P. Ganguly, C. Byrne, A. Breen, S. C. Pillai, Antimicrobial activity of photocatalysts: Fundamentals, mechanisms, kinetics and recent advances, Applied Catalysis B: Environmental 225 (2018) 51-75.

[9] J. Nesic, S. Rtimi, D. Laub, G. M. Roglic, C. Pulgarin, J. Kiwi, New evidence for $\mathrm{TiO}_{2}$ uniform surfaces leading to complete bacterial reduction in the dark: Critical issues, Colloids and Surfaces B: Biointerfaces, 123 (2014) 593-599.

[10] F. Petronella, S. Rtimi, R. Comparelli, R. Sanjines, C. Pulgarin, M. L. Curri, J. Kiwi, Uniform $\mathrm{TiO}_{2} / \mathrm{In}_{2} \mathrm{O}_{3}$ surface films effective in bacterial inactivation under visible light, Journal of Photochemistry and Photobiology A: Chemistry 279 (2014) 1-7.

[11] Bin Guo, Elodie V. Pasco, Irene Xagoraraki, Volodymyr V. Tarabara, Virus removal and inactivation in a hybrid microfiltration-UV process with a photocatalytic membrane, Separation and Purification Technology 149 (2015) 245-254. 
[12] Horst Kisch, Semiconductor Photocatalysis-Mechanistic and Synthetic Aspects, Angew. Chem. Int. Ed. 52 (2013) 812-847.

[13] I. Milosevic, A. Jayaprakash, B. Greenwood, B. van Driel, S. Rtimi, P. Bowen, Synergistic Effect of Fluorinated and $\mathrm{N}$ Doped $\mathrm{TiO}_{2}$ Nanoparticles Leading to Different Microstructure and Enhanced Photocatalytic Bacterial Inactivation, Nanomaterials 7 (2017) 391.

[14] S. Rtimi, R. Sanjines, C. Pulgarin, A. Houas, J.-C. Lavanchy, J. Kiwi, Coupling of narrow and wide band-gap semiconductors on uniform films active in bacterial disinfection under low intensity visible light: Implications of the interfacial charge transfer (IFCT), Journal of Hazardous Materials 260 (2013) 860-868.

[15] A. Pearson, H. Zheng, K. Kalantar-zadeh, S. K. Bhargava, V. Bansal, Decoration of $\mathrm{TiO}_{2}$ Nanotubes with Metal Nanoparticles Using Polyoxometalate as a UV-Switchable Reducing Agent for Enhanced Visible and Solar Light Photocatalysis, Langmuir 28 (2012) 14470-14475.

[16] A. Fujishima, X. Zhang, D. Tryk, $\mathrm{TiO}_{2}$ Photocatalysis and Related Surface Phenomena. Surf. Sci. Rep. 2008, 63, 515-582.

[17] M. Landmann, E. Rauls, W. G. Schmidt, The Electronic Structure and Optical Response of Rutile, Anatase and Brookite $\mathrm{TiO}_{2}$. J. Phys. Condens. Matter 2012, 24, 195503.

[18] J. Zhang, P. Zhou, J. Liu, J. Yu, New Understanding of the Difference of Photocatalytic Activity among Anatase, Rutile and Brookite $\mathrm{TiO}_{2}$. Phys. Chem. Chem. Phys. 2014, 16, 20382-20386.

[19] A. Testino, I. R. Bellobono, V. Buscaglia, C. Canevali, M. D’Arienzo, S. Polizzi, R. Scotti, F. Morazzoni, Optimizing the Photocatalytic Properties of Hydrothermal TiO2 by the Control of Phase Composition and Particle Morphology. A Systematic Approach, J. AM. CHEM. SOC. 129 (2007) 3564-3575.

[20] T. Zhang, X. Hu, M. Fang, L. Zhang, Z. Wang, Synthesis of hierarchical $\mathrm{TiO}_{2}$ nanotube arrays assembled by anatase single crystal nanoparticles, CrystEngComm. 14 (2012) 7656-7661.

[21] M. Mangayayam, J. Kiwi, S. Giannakis, C. Pulgarin, I. Zivkovic, A. Magrez, S. Rtimi, FeOx magnetization enhancing E. coli inactivation by orders of magnitude on $\mathrm{Ag}-\mathrm{TiO}_{2}$ nanotubes under sunlight, Applied Catalysis B: Environmental 202 (2017) 438-445.

[22] A. Bonnefond, E. González, J. M. Asua, J. R. Leiza, J. Kiwi, C. Pulgarin, S. Rtimi, New evidence for hybrid acrylic/ $\mathrm{TiO}_{2}$ films inducing bacterial inactivation under low intensity simulated sunlight, Colloids and Surfaces B: Biointerfaces 135 (2015) 1-7. 
[23] O. Seddiki, C. Harnagea, I. Levesque, D. Mantovani, F. Rosei, Evidence ofantibacterial activity on titanium surfaces through nanotextures, Appl. Surf.Sci. 308 (2014) 275-284.

[24] R. Kadlec, M. Jakubec, Z. Jaglic, A novel flotation technique for the separation of nonadherent microorganisms from a substrate, Lett. Appl. Microbiol. 58(2014) 604-609.

[25] Wagner, C.D.; Riggs, M.W.; Davis, E.L.; Müllenberg, E.G. (Eds) Handbook of X-Ray Photoelectron Spectroscopy, Perkin-Elmer Corp. Phys. Electronic Division, 1979.

[26] J.C. Rivière and S. Myhra, Handbook of Surface and Interface Analysis: Methods for ProblemSolving, $2^{\text {nd }}$ Edition, CRC Press (Taylor \& FrancisGroup), UK 2009, 32-64.

[27] D.A. Shirley, High-Resolution X-Ray photoemission spectrum of the valence bands of gold, Phys. Revs. B5 (1972) 4709-4714.

[28] K. Page, R. G. Palgrave, I. P. Parkin, M. Wilson, S. L. P. Savin and A. V. Chadwick, Titania and silver-titania composite films on glass - potent antimicrobial coatings, J. Mater. Chem. 17 (2007) 95-104.

[29] H. M. Mateus, J. Barba-Ortega, M. R. Joya, Comparison of the Growth of $\mathrm{TiO}_{2}$ Nanotubes in Different Solutions, J. Inorg. Organomet. Pol. Mats. 28 (2018) 612-623.

[30] N. Pugazhenthiran, S. Murugesan, S. Anandan, High surface area $\mathrm{Ag}-\mathrm{TiO}_{2}$ nanotubes for solar/visible-light photocatalytic degradation of ceftiofur sodium, J. Haz. Mat. 263 (2013) 541549.

[31] Shusheng Pan, Xiaolin Liu, Min Guo, Siu fung Yu, Haitao Huang, Hongtao Fan and Guanghai $\mathrm{Li}$, Engineering the intermediate band states in amorphous $\mathrm{Ti}^{3+}$-doped $\mathrm{TiO}_{2}$ for hybrid dyesensitized solar cell applications, J. Mat. Chem. A 3 (2015) 11437.

[32] S. Rtimi, R. Sanjines, M. Andrzejczuk, C. Pulgarin, A. Kulik, J. Kiwi, Innovative transparent non-scattering $\mathrm{TiO}_{2}$ bactericide thin films inducing increased E. coli cell wall fluidity, Surface \& Coatings Technology 254 (2014) 333-343.

[33] S. Rtimi, J. Nesic, C. Pulgarin, R. Sanjines, M. Bensimon and J. Kiwi, Effect of surface pretreatment of $\mathrm{TiO}_{2}$ films on interfacial processes leading to bacterial inactivation in the dark and under light irradiation, Interface Focus 5 (2015) 20140046.

[34] "Revised Effective Ionic Radii and Systematic Studies of Interatomic Distances in Halides and Chalcogenides" By R. D. Shannon. Central Research and Development Department, Experimental Station, E. I. Du Pont de Nemours and Company, Wilmington, Delaware 19898, U.S.A. 
[35] L. H. Ahrens, The use of ionization potentials Part 1. Ionic radii of the elements, Geochim. Cosmochim. Acta 2 (1952) 155-169.

[36] K. Ubonchonlakate, L. Sikong, F. Saito, Photocatalytic disinfection of P.aeruginosa bacterial Ag-doped $\mathrm{TiO}_{2}$ film, Procedia Engineering 32 (2012) 656-662.

[37] S. Rtimi, O. Baghriche, R. Sanjines, C. Pulgarin, M. Bensimon, J. Kiwi, TiON and TiON-Ag sputtered surfaces leading to bacterial inactivation under indoor actinic light, J. Photochemistry and Photobiology A: Chemistry, 256 (2013) 52-63.

[38] J. Prakash, S. Sun, H. C. Swart, R. K. Gupta, Noble metals- $\mathrm{TiO}_{2}$ nanocomposites: From fundamental mechanisms to photocatalysis, surface enhanced Raman scattering and antibacterial applications, Applied Materials Today 11 (2018) 82-135.

[39] H. J. Busscher, H. C. van der Mei, How Do Bacteria Know They Are on a Surface and Regulate Their Response to an Adhering State? PLoS Pathogens 8 (2012) e1002440.

[40] H. H. Tuson and D. B. Weibel, Bacteria-surface interactions, Soft Matter. 9 (2013) 4368-4380.

[41] M. Rabe, D. Verdes, S. Seeger, Understanding protein adsorption phenomena at solid surfaces, Advances in Colloid and Interface Science 162 (2011) 87-106.

[42] M. Kastantin, B. B. Langdon, D. K. Schwartz, A bottom-up approach to understanding protein layer formation at solid-liquid interfaces, Advances in Colloid and Interface Science 207 (2014) 240-252.

[43] F. Lamari, I. Chakroun, S. Rtimi, Assessment of the correlation among antibiotic resistance, adherence to abiotic and biotic surfaces, invasion and cytotoxicity of Pseudomonas aeruginosa isolated from diseased gilthead sea bream, Colloids and Surfaces B: Biointerfaces 158 (2017) 229-236.

[44] O. Baghriche, S. Rtimi, C. Pulgarin, C. Roussel, J. Kiwi, RF-plasma pretreatment of surfaces leading to $\mathrm{TiO}_{2}$ coatings with improved optical absorption and $\mathrm{OH}$-radical production, Applied Catalysis B: Environmental 130-131 (2013) 65-72.

[45] S. Rtimi, C. Pulgarin, R. Sanjines and J. Kiwi, Innovative semi-transparent nanocomposite films presenting photo-switchable behavior and leading to a reduction of the risk of infection under sunlight, RSC Adv. 3 (2013) 16345-16348.

[46] I. Ahmad and C.-W. Kan, Visible-Light-Driven, Dye-Sensitized $\mathrm{TiO}_{2}$ Photo-Catalyst for SelfCleaning Cotton Fabrics, Coatings 7 (2017) 192. 
[47] B. Nowack, H. F. Krug, and M. Height, 120 Years of Nanosilver History: Implications for Policy Makers, Environ. Sci. Technol. 45 (2011) 1177-1183.

[48] S. Rtimi, M. Pascu, R. Sanjines, C. Pulgarin, M. Ben-Simone, A. Houasa, J.-C. Lavanchy, J. Kiwi, ZrNO-Ag co-sputtered surfaces leading to E. coli inactivation under actinic light: Evidence for the oligodynamic effect, J. Haz. Mat. 260 (2013) 860-868.

[49] S. Rtimi, V. Nadtochenko, I. Khmel and J. Kiwi, Evidence for differentiated ionic and surface contact effects driving bacterial inactivation by way of genetically modified bacteria, Chem. Comm. 53 (2017) 9093.

[50] S. Rtimi, V. Nadtochenko, I. Khmel, M. Bensimon and J. Kiwi, First unambiguous evidence for distinct ionic and surface-contact effects during photocatalytic bacterial inactivation on $\mathrm{Cu}-$ Ag films: Kinetics, mechanism and energetics, Mat. Tod. Chem. 6 (2017) 62-74.

[51] C. Ruales-Lonfat, N. Benitez, A. Sienkiewicz, C. Pulgarin, Deleterious effect of homogeneous and heterogeneous near-neutral photo-Fenton system on Escherichia coli. Comparison with photo-catalytic action of $\mathrm{TiO}_{2}$ during cell envelope disruption, Applied Catalysis B: Environmental 160-161 (2014) 286-297. 


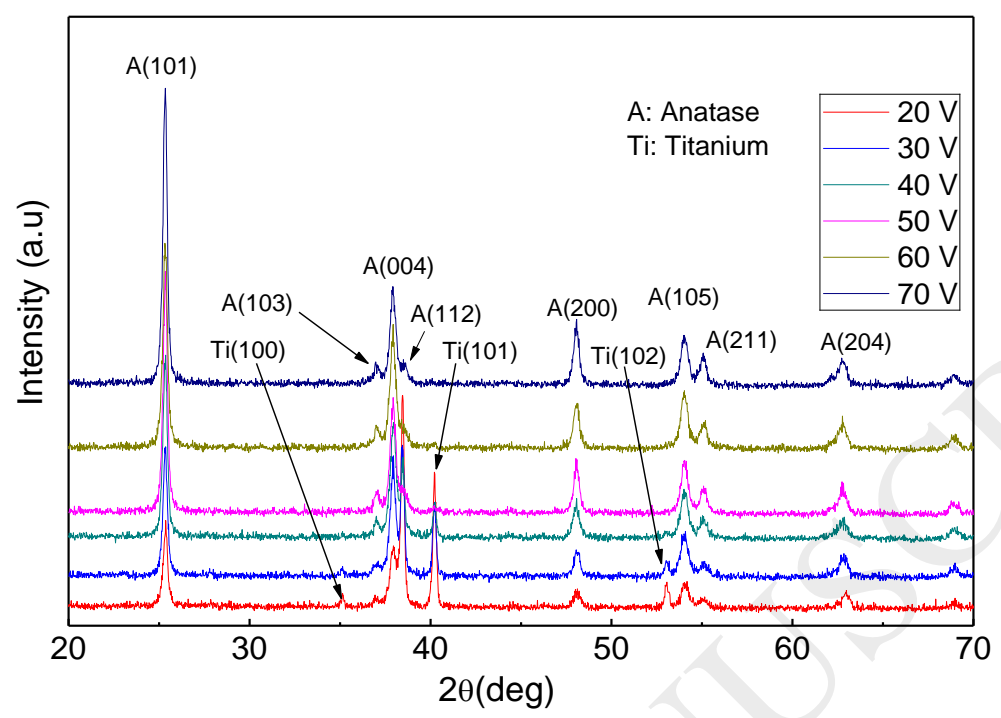

Figure 1. XRD patterns of Ag-NPs decorated $\mathrm{TiO}_{2}-\mathrm{NTs}$ as a function of anodization potential.
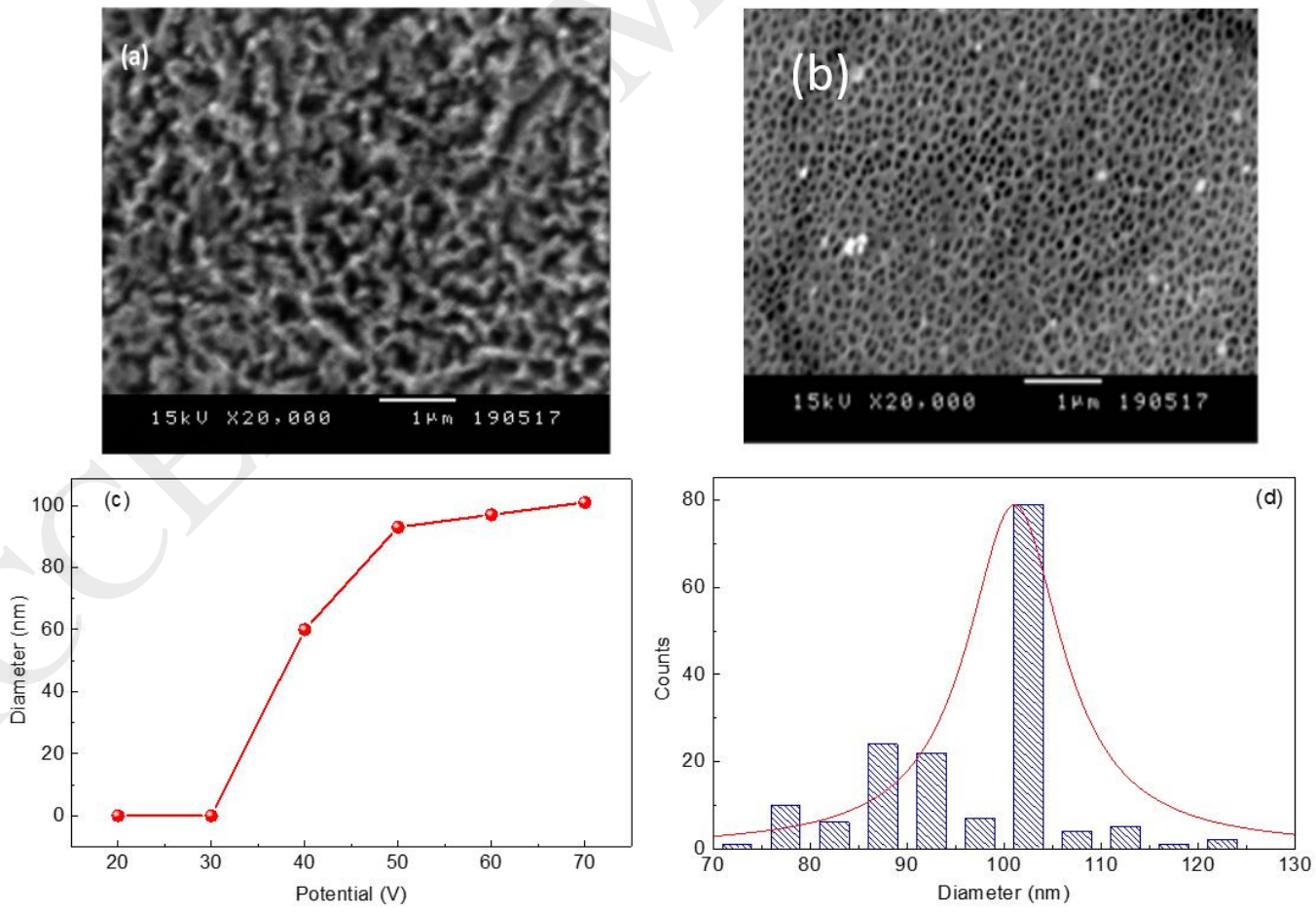
Figure 2. SEM top view images of $\mathrm{Ag}-\mathrm{NPs}$ decorated $\mathrm{TiO}_{2}-\mathrm{NTs}$ anodized respectively under : (a) potential $20 \mathrm{~V}$, and (b) $60 \mathrm{~V}$. (c) the variation of diameter of the $\mathrm{TiO}_{2}-\mathrm{NTs}$ as function of anodization potentials, and (d) the diameter size distribution of $\mathrm{TiO}_{2}-\mathrm{NTs}$ anodized at $60 \mathrm{~V}$. 

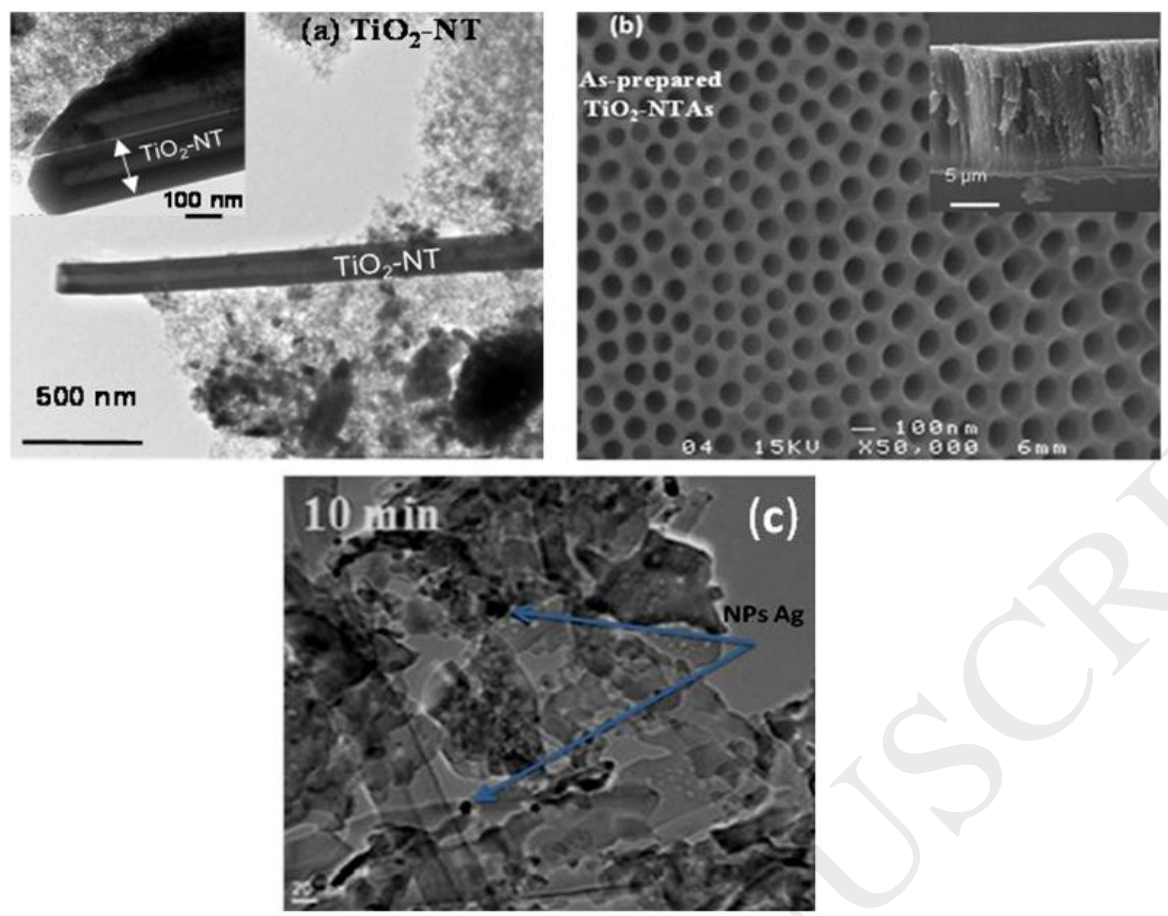

Figure 3. Typical TEM micrographs of an undecorated $\mathrm{TiO}_{2}-\mathrm{NT}$ (a) and a $\mathrm{TiO}_{2}-\mathrm{NT}$ decorated with Ag-NPs during 10 min of photo-reduction time (b), SEM top-view image of the prepared $\mathrm{TiO}_{2}$ NTs $(60 \mathrm{~V})$, and (c) TEM of Ag-NPs prepared by photo-reduction method for $10 \mathrm{~min}$.

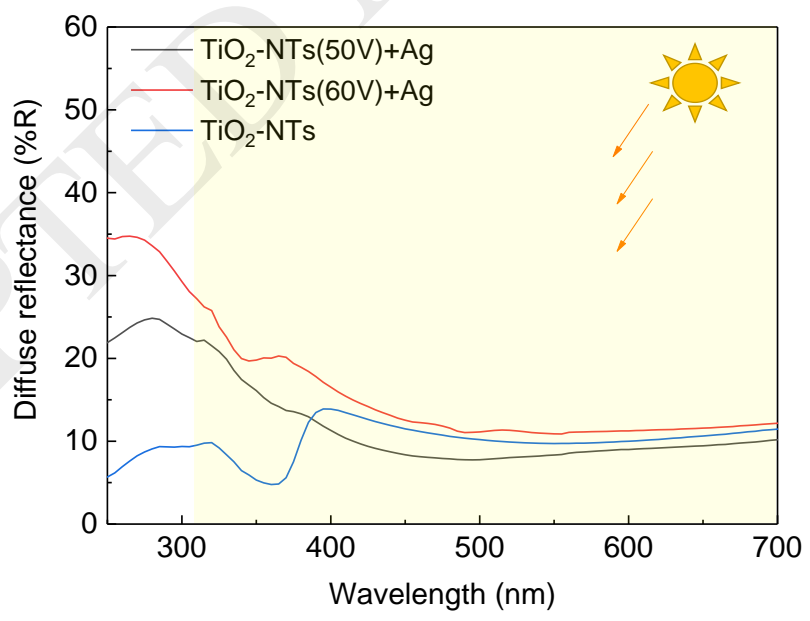

Figure 4. Diffuse reflectivity spectra of $\mathrm{TiO}_{2}-\mathrm{NT}$ s decorated with Ag-NPs grown at different anodization potential. The yellow zone in the figure represents the emission range of the applied light (310-800 $\mathrm{nm})$. 
a)

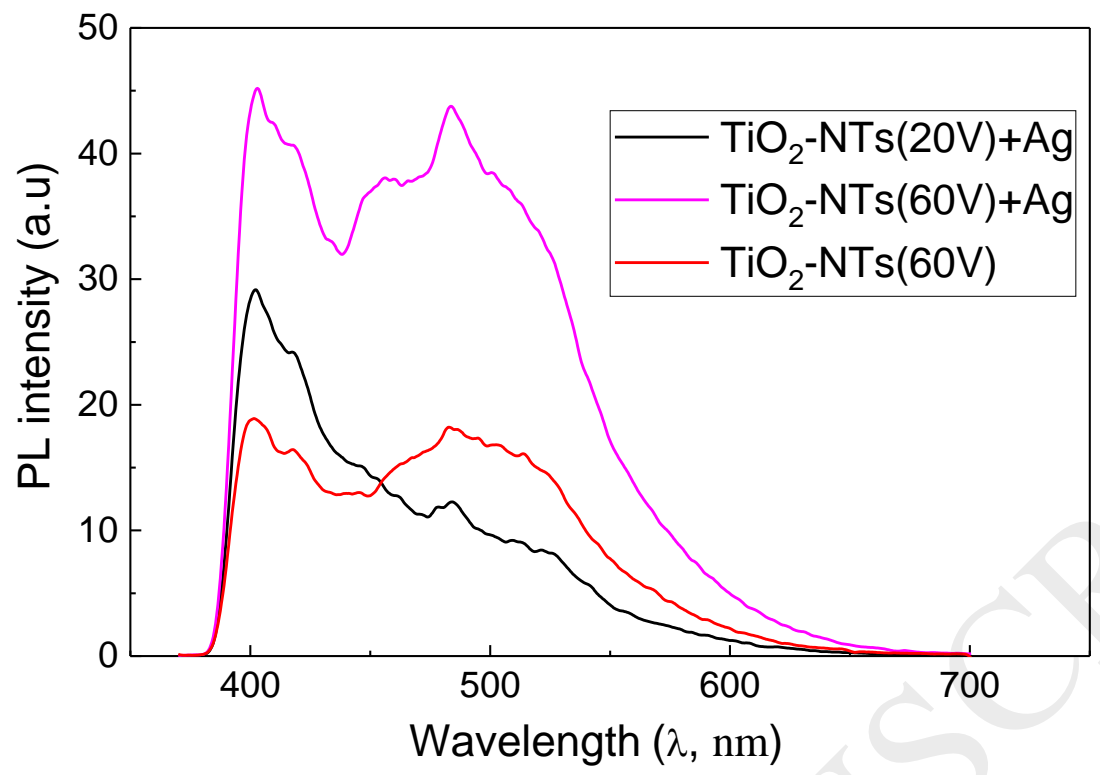

b)



Figure 5. a) Typical PL spectra of Ag-NPs decorated $\mathrm{TiO}_{2}-\mathrm{NT}$ s anodized at different potential; b) mechanism of bacterial inactivation on $\mathrm{Ag}$ decorated $\mathrm{TiO}_{2}-\mathrm{NTs}$. 


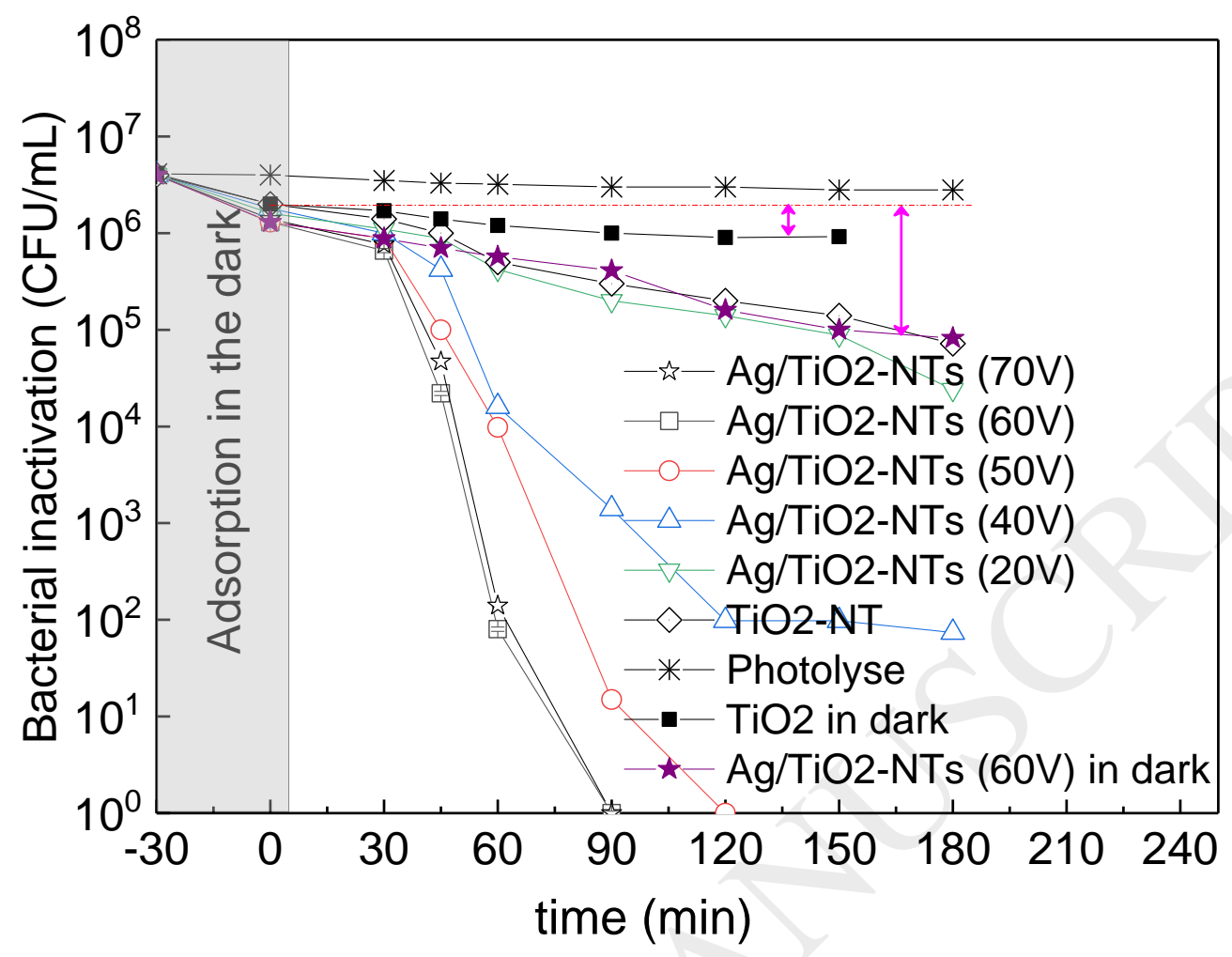

Figure 6. Bacterial inactivation on $\mathrm{TiO}_{2}-\mathrm{Nts}$ and $\mathrm{TiO}_{2}-\mathrm{NTs}+\mathrm{Ag}$. Used light: solar simulated light $\left(50 \mathrm{~mW} / \mathrm{cm}^{2}, 310-800 \mathrm{~nm}\right)$. For more details, see text. (Error bars: SD, $\left.\mathrm{n}=5 \%\right)$.

Table 1: $\mathrm{TiO}_{2}-\mathrm{NT}$ diameter and Ag-NPs size expressed as mean value ( \pm standard deviation). 




